American Journal of Agricultural and Biological Sciences 3 (3): 617-622, 2008

ISSN 1557-4989

(C) 2008 Science Publications

\title{
Nutrient Contents per Serving of Twelve Varieties of Cooked Rice Marketed in Jordan
}

\author{
${ }^{1}$ Jafar M. El-Qudah, ${ }^{1}$ Basem F. Dababneh, ${ }^{1}$ Ala'a A. Al-Bakheit, ${ }^{2}$ Maisa M. Al-Qudah, \\ ${ }^{3}$ Abdullah Al-Rawashdeh, ${ }^{4}$ Moayad Khataibeh, ${ }^{4}$ Khalid Abu-Alruz and ${ }^{5}$ Khalil I. Ereifej \\ ${ }^{1}$ Department of Nutrition and Food Processing, Al-Balqa Applied University, Al-Salt, Jordan \\ ${ }^{2}$ Department of Allied Medical Sciences, Al-Balqa Applied University, Al-Zarqa, Jordan \\ ${ }^{3}$ Department of Nutrition and Food Technology, Mu'tah University, Al-Karak, Jordan \\ ${ }^{4}$ Department of Food and Nutrition, Applied Sciences University, Amman, Jordan \\ ${ }^{5}$ Department of Nutrition and Food Technology, \\ Jordan University of Science and Technology, Irbid, Jordan
}

\begin{abstract}
Jordan imports rice from different countries without any quality preferences. Twelve varieties of cooked rice marketed in Jordan were analyzed. The content per serving of these varieties were computed for energy, protein, carbohydrates, fat, calcium, sodium, potassium, magnesium, manganese, copper, iron and phosphorous. The protein content per serving found to range from $0.49 \mathrm{~g}$ for La Cigala rice to $6.2 \mathrm{~g}$ for Harvest rice. The fat content for all rice brands was less than $0.37 \mathrm{~g}$ per serving. The energy content ranged from $172.12 \mathrm{~g} /$ serving for Basmati rice to $212.25 \mathrm{~g} / \mathrm{serving}$ for Sun White rice. Generally, all rice varieties contain significant amounts of minerals per serving. Ruzzana found to contain the highest level of calcium $(38.2 \mathrm{mg} / \mathrm{serving})$ and Amber the lowest calcium content $(6.7 \mathrm{mg} /$ serving). Magnesium content found to range from $5.7 \mathrm{mg} / \mathrm{serving}$ for Royal Umberella rice to $16.3 \mathrm{mg} / \mathrm{serving}$ for Ruzzana rice. Consumption of one serving of Harvest cooked rice will cover $13.5 \%$ of the daily requirement of protein for females and $11.1 \%$ for males. Manganese content of one serving of Harvest, Sun White, Abu bent and La Cigala will cover $22.2 \%$ of the daily requirements for females and $14.7 \%$ for males, while consumption of one of Basmati, Sos rice or Amber will cover only $11.1 \%$ and 8.75 of requirement for females and males respectively. Planning a healthful diet is not a simple task. Dietary Reference Intake planning and assessing the diets of individuals or groups of healthy individuals according to their stage of life and sex. Food choice is a function of many factors, including personal preferences, habits, ethnic heritage and tradition. Dietary guidelines for Americans, consider whole grain products like rice are among the food groups that form the basis of a healthy diet. Including rice as part of a healthy, balanced diet can be linked to overall healthier eating patterns. Rice eaters are more likely to eat a diet consistent with the 2005 Dietary Guidelines for Americans.
\end{abstract}

Key words: Rice, nutritive value, serving size, meal planning, minerals, RDA, Jordan

\section{INTRODUCTION}

Rice is one of the most important cereal crops and commercially, more than two thousand varieties of rice are grown throughout the world ${ }^{[1,2]}$. It is a nutrient-rich complex carbohydrate, fit's today's recommendations to get the most nutrition from calories consumed and provide the body energy needs for physical activity. All of the major health organizations recommended that adults get $45-65 \%$ of their calories from carbohydrates ${ }^{[3]}$. Today, the world faces the problem of shortage food supply, which makes the malnutritional problem and its consequences in the undeveloped countries a major problem ${ }^{[4]}$.
Rice, which is the staple food of nearly two third of the world's population, is a nutrient-rich complex carbohydrates that has only a trace of fat and naturally sodium, gluten and cholesterol free ${ }^{[3,5]}$. Due to its mild flavor, rice also complements many other healthy foods, including vegetables, lean beef, seafood and poultry, beans and soyfoods. Research findings show that rice, which is rich in many functional components such as micronutrients, aminobutyric acid (GABA), glutelin, resistant starch, fiber, unsaturated fatty acids, amino acids and free radical scavenger, these are known to prevent hypertension, assist in curing nephritic disease, diabetes caused by imbalanced food intake, chemical contamination ${ }^{[6]}$ and protect the body

Corresponding Author: Jafar M. El-Qudah, Faculty of Agricultural Technology, Department of Nutrition and Food Processing, Al-Salt 19117, Jordan Tel: (962-5) 3491111 Fax. (962-5) 3530469 
from heart diseases, certain cancers and osteoporosis $^{[3,7]}$.

Rice is a staple for a large part of the world's human population, especially in tropical Latin America and East, South and Southeast Asia. Rice has the potential to improve nutrition, boast food security, foster rural development and support sustainable landcare. Rice provides more than one fifth of the calories consumed worldwide by humans. World production of rice has raisin steadily from about 200 million tons of paddy rice in 1960-600 million tons in 2004. In the year 2004, the top three producer countries were china (26\% of world production), India (20\%) and Indonesia $(9 \%)^{[8,9,10]}$. Between 1961 and 2002, per capita consumption of rice increased by $40 \%$. Rice consumption is the highest in Asia, in which the average per capita consumption is higher than 80 $\mathrm{kg} /$ person per year. In South America, Africa and the Middle East, the per capita consumption averages are between 30 and $60 \mathrm{~kg} /$ person per year. People in the developed West, including Europe and the United States, consume less than $10 \mathrm{~kg} /$ person per year ${ }^{[11-14]}$. Before consuming rice it is subjected to different processing procedure that involve the milling process, which remove the outer protective layers of rice caryopsis to yield the milled rice ${ }^{[5,15]}$. Various methods are used to determine the digestibility of proteins and rice protein scores higher than many other grains in protein digestibility. According to a World Health Organization reports, eggs, milk, cheese and peanut butter have a relative protein digestibility score of 100 , which means that the protein in these foods is readily digestible by the body. Milled rice has a score of 93, which is higher than most other plant-based foods. Beans have a score of 82 while soy flour, wheat and oatmeal score $90^{[2]}$.

Majority of consumers prefer the well-milled white rice with little or no bran remaining on the endosperm, which reduces its content from protein, fat, vitamins and minerals, thus reducing its nutritional value ${ }^{[5]}$. Planning a healthful diet is not a simple task. Food choice is a function of many factors, including personal preferences, habits, ethnic heritage and tradition ${ }^{[16]}$. Dietary guidelines for Americans, enriched and whole grain products like rice are among the food groups that from the basis of a healthy diet. Dietary Reference Intake planning and assessing the diets of individuals or groups of healthy individuals according to their stage of life and sex ${ }^{[17]}$.

Jordan imports rice from different countries without any quality preferences. The total quantity imported during 2003 was 125417 ton. Consumption per capita has increased from $20.0 \mathrm{~kg}$ in 2002 to 23.3 $\mathrm{kg}$ in $2003^{[18]}$. The objective of this study is to determine the content of energy, protein, carbohydrates, fat, calcium, sodium, potassium, magnesium, manganese, copper, iron and phosphorous per serving of cooked rice from twelve different varieties of rice marketed in Jordan, then determining the contribution of one serving consumed by adult males and females of the Recommended Dietary Allowances (RDA) as percentage of the RDA.

\section{MATERIALS AND METHODS}

Twelve brands of rice marketed in Jordan were included in this study. Chemical composition, weight of 100 and 1000 grain, percent of broken grain, percent of water absorption, hectoliter and cooking time were previously analyzed in our previous work ${ }^{[19]}$. Based on these analysis, we recalculate the content of each rice brand from energy, carbohydrates, fat, protein, calcium, sodium, potassium, magnesium, manganese, copper, iron and phosphorous were obtained for each serving by converted the amounts of each nutrients found in $100 \mathrm{~g}$ of each brand of rice into one serving. For example, the proximate analysis of Harvest rice type for protein, carbohydrates, fat was $10.1,70.0$ and $1.0 \mathrm{~g} / 100 \mathrm{~g}$ respectively. If one serving of this type equals $1 / 3$ cup $(61.4 \mathrm{~g}), 1$ serving should contain $6.2 \mathrm{~g}$ protein, $45.42 \mathrm{~g}$ carbohydrate and $0.61 \mathrm{~g}$ fat.

Physical characteristics: color, grain length and country of origin for these varieties of rice are presented in Table 1.

The serving size in this work was determined according to USDA food composition table, one serving of cooked parboiled unenriched white long grain rice is considered to be about $52.1 \mathrm{~g}$, (one cup = $158 \mathrm{~g}$ ), whereas for the cooked white medium grain rice is about $61.4 \mathrm{~g}$, (one cup $=186 \mathrm{~g}$ ).

The percent RDA for males and females of each content of the different rice brands were calculated as follows:

Table 1: Physical characteristics of raw rice marketed in Jordan

\begin{tabular}{llll}
\hline Commercial rice brand & Color & Grain length & Country of origin \\
\hline Harvest & White & Medium & USA \\
Ruzzana & Gold & Long & Saudi Arabia \\
Basmati & White & Long & India \\
California & White & Medium & USA \\
Sun bird & White & Medium & Egypt \\
Sun white & White & Medium & Australia \\
Abu bent & Gold & Long & USA \\
Sos rice & White & Long & Spain \\
Dux rice & White & Medium & Spain \\
La cigala & White & Medium & Spain \\
Royal Ambrella & White & Long & Thailand \\
Amber & Brown & Long & Iraq \\
\hline
\end{tabular}


Am. J. Agri. \& Biol. Sci., 3 (3): 617-622, 2008

- $\%$ RDA = nutrient content*100/RDA

- In case of $\mathrm{Na}$ and $\mathrm{K}, \% \mathrm{RDA}=$ (nutrient content*100/RDA)*1000

- In case of $\mathrm{Cu}$, RDA $\%=$ (nutrient content*100)/(RDA/1000)

The percentage of protein, minerals intake for males and females were compared to Dietary Reference Intake $(\mathrm{DRI})^{[20]}$. For example, the RDA for adult females for protein is $46 \mathrm{~g} / \mathrm{d}$. Consuming one serving of California rice type will cover $9.8 \%$ of the daily protein requirement.

Chemical composition: Protein $(\mathrm{N} * 6.25)$ and crude fat were determined according to AOAC (1984) procedure $^{[21]}$. Carbohydrate content was calculated by difference.

Mineral analysis: $\mathrm{Ca}, \mathrm{Na}, \mathrm{K}, \mathrm{Mg}, \mathrm{Mn}, \mathrm{Cu}$ and $\mathrm{Fe}$ concentrations were determined according to the procedure outlined ${ }^{[22]}$. Atomic absorption spectrophotometer was used. Phosphorous levels were determined according to Fiske and Subbarow (1925) ${ }^{[23]}$. Mineral concentration values were computed on dry weight basis.

Statistical analysis: The statistical significance of the data was analyzed using the paired student's t-test method $^{[24]}$. Significant differences between males and females were presented at $\mathrm{p}<0.01$.

\section{RESULTS AND DISCUSSION}

Jordan imports large amounts of rice from many countries, manly from USA, followed by Australia, Egypt and Thailand (Table 1). The average annual cost between 1995-2003 is about 25.5 million J.D (\$ 36.4 million) which shows the economic importance of imported rice to be of high quality.

Data on the effect of cooking on chemical composition of rice brands are shown in Table 2. The protein content per serving found to range from $0.49 \mathrm{~g}$ for La Cigala rice to $6.2 \mathrm{~g}$ for Harvest rice. The fat content for all rice brands was less than $0.37 \mathrm{~g}$ per serving. The energy content ranged between 172.17 $\mathrm{g} /$ serving for Basmati rice to $212.25 \mathrm{~g} /$ serving for sun white rice.

Data on minerals analysis of cooked rice are shown in Table 3. Generally, all rice varieties contain significant amounts of minerals per serving. Ruzzana found to contain the highest level of calcium (38.2 $\mathrm{mg} / \mathrm{serving}$ ) and Amber the lowest calcium content (6.7 $\mathrm{mg} / \mathrm{serving}$ ). Magnesium content found to range from $5.7 \mathrm{mg} /$ serving for Royal Umbrella rice to 16.3 $\mathrm{mg} / \mathrm{serving}$ for Ruzzana rice.
Table 2: Rice varieties, macronutrient and energy in a serving of cooked rice $(\bullet)$

\begin{tabular}{lllll}
\hline Rice brand & CHO $(\mathrm{g})$ & Fat $(\mathrm{g})$ & Protein $(\mathrm{g})$ & Energy (kcal) \\
\hline Harvest & 45.42 & 0.61 & 6.20 & 211.97 \\
Ruzzana & 38.94 & 0.42 & 4.64 & 182.1 \\
Basmati & 35.98 & 0.73 & 5.42 & 172.17 \\
California & 46.1 & 0.49 & 4.54 & 206.97 \\
Sun bird & 46.77 & 0.55 & 4.73 & 210.95 \\
Sun white & 46.77 & 0.37 & 5.46 & 212.25 \\
Abu bent & 40.1 & 0.42 & 5.47 & 186.06 \\
Sos rice & 40.88 & 0.26 & 3.86 & 181.3 \\
Dux rice & 45.36 & 0.31 & 5.46 & 206.1 \\
La cigala & 43.95 & 0.49 & 0.49 & 182.17 \\
Royal Ambrella & 41.82 & 0.26 & 4.28 & 186.74 \\
Amber & 40.20 & 0.36 & 5.74 & 187 \\
\hline
\end{tabular}

(•) Values are average of three replicates

According to t-test at $(\mathrm{p}=0.99)$, there is a significant difference between males and females, in protein, magnesium, manganese and iron consumption as percentage of RDA, (Table 4). The female consumption was significantly better than the male consumption in these nutrients.

Consumption of one serving of Harvest cooked rice will cover $13.5 \%$ of the daily requirement of protein for females and $11.1 \%$ for males.

As shown in Table 4, Manganese content of one serving of Harvest, Sun white, Abu bent and La Cigala will cover $22.2 \%$ of the daily requirement for females and $17.4 \%$ for males, while consumption of one serving of Basmati, Sos rice or Amber will cover only 11.1 and $8.7 \%$ of the daily requirement for females and males respectively.

The cooked rice significantly lost some nutrients (proteins, lipids, carbohydrates and minerals). This is expected because rice usually is soaked with warm water for nearly $1 \mathrm{~h}^{[19]}$. Nutrient values showed in Table 2 and 3 found to be comparable with those reported ${ }^{[1,5]}$.

Cereals are a major source of carbohydrates, proteins, fats, minerals and vitamins to the consumers mainly vegetarian population worldwide. Among the twelve varieties of rice investigated in this study, Ruzzana rice seems to have high amounts of minerals (Table 3). Minerals are essential for normal metabolic functions and are required components in a balanced diet. High potassium, calcium and magnesium could be helpful in improving muscle activity in patients suffering from muscle wasting ${ }^{[1]}$. Rice is a gluten-free and is an important stable in diets of individuals with celiac disease, gluten intolerance or sensitivity.

The 2005 Dietary Guidelines/ My Pyramid recommended adults eat from six to over 10 servings of grains per day, depending upon calorie needs and that at least half of those grains should come from whole grains. Since rice is the most popular grain throughout the world, it makes good sense for people who are 
Am. J. Agri. \& Biol. Sci., 3 (3): 617-622, 2008

Table 3: Rice varieties and mineral in a serving of cooked rice (mg per serving) $(\bullet)$

\begin{tabular}{lllllllll} 
Rice & Calcium & Sodium & Potassium & Magnesium & Manganese & Copper & Iron & Phosphorous \\
\hline Harvest & 20.0 & 14.2 & 24.9 & 10.0 & 0.4 & 0.5 & 1.2 & 0.4 \\
Ruzzana & 38.2 & 21.6 & 49.4 & 16.3 & 0.3 & 0.4 & 1.0 & 0.5 \\
Basmati & 20.8 & 21.6 & 37.1 & 12.1 & 0.2 & 0.3 & 1.3 & 0.4 \\
California & 11.7 & 24.6 & 26.6 & 10.3 & 0.3 & 0.3 & 1.0 & 0.4 \\
Sun bird & 18.2 & 27.7 & 31.1 & 11.5 & 0.3 & 0.4 & 0.9 & 0.4 \\
Sun white & 10.6 & 16.0 & 26.8 & 14.2 & 0.4 & 0.4 & 0.8 & 0.4 \\
Abu bent & 23.6 & 22.8 & 40.6 & 13.8 & 0.4 & 0.4 & 1.2 & 0.5 \\
Sos rice & 13.7 & 13.8 & 19.1 & 8.9 & 0.2 & 0.3 & 0.6 & 0.3 \\
Dux rice & 27.1 & 21.5 & 20.9 & 12.1 & 0.3 & 0.4 & 0.6 & 0.6 \\
La cigala & 16.3 & 16.6 & 17.7 & 14.5 & 0.4 & 0.4 & 1.0 & 0.4 \\
Royal Umbrella & 16.3 & 14.0 & 12.3 & 5.7 & 0.3 & 0.3 & 1.0 & 0.4 \\
Amber & 6.7 & 7.8 & 29.5 & 15.6 & 0.2 & 0.6 & 1.1 & 0.7 \\
\hline
\end{tabular}

$(\bullet)$ Values are average of three replicates

Table 4: Percentage of RDA of nutrients by consuming one serving of cooked rice for adult males and females. M: Males, F: Female

\begin{tabular}{|c|c|c|c|c|c|c|c|c|c|c|c|c|c|c|c|c|c|c|}
\hline \multirow[b]{2}{*}{ Type of rice } & \multicolumn{2}{|c|}{ Protein } & \multicolumn{2}{|c|}{ Calcium } & \multicolumn{2}{|c|}{ Sodium } & \multicolumn{2}{|c|}{ Potassium } & \multicolumn{2}{|c|}{ Magnesium } & \multicolumn{2}{|c|}{ Manganese } & \multicolumn{2}{|c|}{ Copper } & \multicolumn{2}{|l|}{ Iron } & \multicolumn{2}{|c|}{ Phosphorous } \\
\hline & $\mathrm{M}$ & $\mathrm{F}$ & $\mathrm{M}$ & $\mathrm{F}$ & M & $\mathrm{F}$ & $\mathrm{M}$ & $\mathrm{F}$ & $\mathrm{M}$ & $\mathrm{F}$ & $\mathrm{M}$ & $\mathrm{F}$ & $\mathrm{M}$ & $\mathrm{F}$ & $\mathrm{M}$ & $\mathrm{F}$ & $\mathrm{M}$ & $\mathrm{F}$ \\
\hline Harv-est & 11.1 & 13.5 & 2.0 & 2.0 & 0.9 & 0.9 & 0.5 & 0.5 & 2.4 & 3.1 & 17.4 & 22.2 & 55.6 & 55.6 & 15 & .7 & 06 & 0.06 \\
\hline Ruzz & & 10 & 3.8 & 3 & & 1 & & 1 & & 5 & 13.0 & & 4 & .4 & 12.5 & 6 & 7 & 0.07 \\
\hline Bas & 0 & 11.7 & 2.1 & 2. & 1.4 & 1.4 & 0.8 & 0. & 2. & 3.8 & 8.7 & 1 & .3 & .3 & 16.3 & 2 & 6 & 0.06 \\
\hline Calif-o & 8 & 9.8 & 1.2 & 1.2 & 1.6 & 1.6 & 0.6 & 0.6 & 2.5 & 3.2 & 13.0 & 16.7 & 33.3 & 33.3 & 12.5 & 5.6 & 6 & 0.06 \\
\hline Sun- 1 & 8.4 & 10.2 & 1.8 & 1.8 & 1.8 & 1.8 & 0.7 & 0.7 & 2.7 & 3.6 & 13.0 & 16.7 & 44.4 & 44.4 & 11.3 & 5.0 & 6 & 0.06 \\
\hline Sun- & 9 & 12.0 & 1.1 & 1.1 & 1.1 & 1.1 & 0.6 & 0.6 & 3.4 & 4.4 & 17.4 & 22.2 & 44.4 & 44.4 & 10.0 & 4.4 & 6 & 0.06 \\
\hline Abu -bent & 9.8 & 12.0 & 2.4 & 2.4 & 1.5 & 1.5 & 0.9 & 0.9 & 3.3 & 4.3 & 17.4 & 22.2 & 44.4 & 44.4 & 15 & 6.7 & 77 & 0.07 \\
\hline & & 8 & 1.4 & 1.4 & 0.9 & 0.9 & & 0 & 2.1 & 2.8 & 8.7 & & 33.3 & 3 & 7 & 3 & & 0.04 \\
\hline & & 12.0 & 2.7 & 2. & 1.4 & 1. & 0 & 0 & 2.9 & 3 & 13.0 & 7 & 44.4 & 44.4 & 7 & 3 & 9 & 0.09 \\
\hline La- & & 1.1 & 1.6 & $1 .($ & 1.1 & 1.1 & 0.4 & 0.4 & 3.5 & 4.5 & 17.4 & 22.2 & 44.4 & 44.4 & 12.5 & 5.6 & 0.06 & 0.06 \\
\hline Ro & .1 & 9.3 & 1.6 & 1.6 & 0.9 & 0.9 & 0.3 & 0.3 & 1.4 & 1.8 & 13.0 & 16.7 & 33.3 & 33.3 & 12.5 & 5.6 & 0.06 & 0.06 \\
\hline Amb- er & 10.2 & 12.4 & 0.7 & 0.7 & 0.5 & 0.5 & 0.6 & 0.6 & 3.7 & 4.9 & 8.7 & 11.1 & 66.7 & 66.7 & 13.8 & 6.1 & 0.1 & 0.1 \\
\hline
\end{tabular}

looking to adopt healthier eating style and maintain a healthy weight. It has long been known that rice is the foundation of a healthy diet for much of the world, especially in Asia and the Mediterrian ${ }^{[25]}$.

Approximately $70 \%$ of the world's 1.3 billion poor people live in Asia, where rice is the staple food. To some extent, this reflects Asia's large population, but even in relative terms malnutrition appears to affect a substantially larger share of the population in South Asia than in Africa. For these people, rice is the most important commodity in their daily lives.

During 1999 in Bangladesh, Vietnam and Myanmar, the average citizen consumes 150-200 kg annually, which accounts for two-thirds or more of caloric intake and approximately $60 \%$ of daily protein consumption. Even in relatively wealthier countries such as Thailand and Indonesia, rice still accounts for nearly $50 \%$ of calories and one-third or more of protein. In Egypt during the same year, the rice consumption was $41 \mathrm{~kg} /$ capita, this accounts $13 \%$ of calories and $9 \%$ of protein from rice ${ }^{[26]}$. Despite increasing production, sub-Saharan Africa is expected to import larger quantities of rice each year to meet rising consumption, driven by a rapidly expanding population. No decline in per capita disappearance is expected for sub-saharan
Africa, even with stronger economic growth, incomes remain too low for the majority of consumers to shift away from rice to higher valued foods. Imports accounts for slightly less than half of the rice consumed in the region. Strong consumption growth is behind import expansion by the Middle East. Except for Iran and Turkey, the Middle East grows very little rice and imports account for almost two-thirds of its annual rice needs. Most of the Middle East is a high-quality import market $^{[10,27]}$.

Over $85 \%$ of the calories contained in rice come from carbohydrates with less than one percent from fat. Carbohydrates are the key energy-supplying nutrient for the body. Without adequate carbohydrates, the body cannot supply the muscles, brain and virtually every living cell with the carbohydrate energy it needs. Research from Massachusetts Institute of Technology has found that carbohydrates play a key role in mood by regulating the production of mood-elevating neurotransmitter, serotonin, in the brain ${ }^{[28]}$. Because it is primarily comprised of complex carbohydrates, rice has a moderate glycemic index (GI) value, which is important for individuals who are following a GIcontrolled lifestyle. In addition, the way in which rice is eaten reduces its blood sugar response even further. 
Since rice is rarely eaten alone, unlike bread or hot cereals, the total glycemic load of the meal becomes even more important than the GI value of a particular food.

Since rice is generally eaten with vegetables, lean protein sources or beans, the glycemic load of a rice meal will generally be $\operatorname{low}^{[29]}$. A recent Iowa State University Study found that people who eat rice have healthier diets, eat more fruits and vegetables, consume less added sugar and fat and are likely to have a lower body mass index than non-rice eaters. The data suggest that including rice as part of a healthy, balanced diet can be linked to overall healthier eating patterns. The data also indicate that rice eaters are more likely to eat a diet consistent with the 2005 Dietary Guidelines for Americans ${ }^{[30]}$.

\section{CONCLUSION}

We found that marketed rice brands in Jordan varied significantly in their physical characteristics, chemical composition and mineral concentrations. With regard to protein content per serving, it was found that Harvest rice contained $6.2 \mathrm{~g}$, whereas La Cigala rice contained $0.5 \mathrm{~g}$ per serving. The content of minerals differs between all of these brands

\section{ACKNOWLEDGMENTS}

The authors would like to thank Prof. Fadil AlMohammadi, for his valuable comments on the manuscript.

\section{REFERENCES}

1. Deepa, G., V. Singh and K.A. Naidn, 2007. Nutrient composition and physicochemical properties of Indian medicinal rice-njavara. Food Chem., 106 : 165-171. DOI:10.1016/j.foodchem.2007.05.062

2. Itani, T., M. Tamaki, E. Arai and T. Horino, 2002. Distribution of amylose, nitrogen and minerals in rice kernel with various characters. J. Agric. Food Chem., 50: 5326-5332. doi: 10.1021/jf020073x http://dx.doi.org/10.1021\%2Fjf020073x.

3. Tetens, I., S. H. Thilsted, N. H. Choudhury and N. Hassan, 1998. The rice-based diet in Bangladesh in the context of food and nutrition security. Scandinavian Journal of Nutrition, 42: 77-80.

4. Sheehy, J.E., A. Elmido, G. Centeno and P. Pablico, 2005. Searching for new plants for climate change. J. Agric. Meteorol., 60: 463-468, www.jstage.jst.go.jp/browse/agrmet
5. Roy, P., T. Ijiri, H. Okadome, D. Nei, T. Orikasa, N. Nakamura and T. Shiina, 2008. Effect of processing conditions on overall energy consumption and quality of rice. J. Food Eng., 89: 343-348. doi:10.1016/j.jfoodeng.2008.05.015.

6. Ning, S.U., W. Xiang-Yuan, Z. Hu-Qu and W. Jian-Min, 2008. Progress and prospect of functional rice researches. Agric. Sci. China, 7: 19. www.chinaagrisci.com/V2/En/Index.asp - 19k

7. White, P.T., 1994. Rice: The Essential Harvest. Natl. Geog., pp: 48-79. www.nationalgeographic.com/.../activities/04/popu p/literature.html http://www.nationalgeographic. com/.../activities/04/popup/literature.html

8. Cohen, J.E., K. Schoenly, K.L. Heong, H. Justo, G. Aride, A.T. Barrion and J.A. Litsinger, 1994. A food web approach to evaluating the effect of insectiside spraying on insect pest population dynamic in Philippine irrigated rice ecosystem. J. Applied Ecol., 31: 747-763. doi: 10.2307/2404165.

9. Gupta, R. and A. Seth, 2007. A review of resource conserving technologies for sustainable management of the rice-wheat cropping systems of the Indo-Gangetic plains (IGP). Crop Protection, 26: 436-447.

10. Food and Agriculture Organization of the United Nations, 2002. FAO Rice Information, Plant Production and Protection Division, vol. 3, Rome, Italy.

11. Crawford, G.W. and C. Shen, 1998. The origions of rice agriculture: Recent progress in East Asia. Antiquity, 72: 858-866.

12. FAO, 2000. Production Year Book; FAO, Rome. www.fao.org/ES/ess/yearbook/vol_1_2/pdf/India.p $\mathrm{df}$

13. FAO, Rice Market Monitor, 2008, April 2008, Volume XI - Issue No. 1, www.fao.org/es/ESC/en/ 15/70/highlight 71.html http://www.fao.org/es/ ESC/en/15/70/highlight 71. html

14. Chotimarkorn, C., S. Benjakul and N. Silalai, 2008. Antioxidative effect of rice bran extracts on refined tuna oil during storage. Food Res. Int., 41: 616622. DOI: 10.1016/j.foodres.2008.04.002

15. Lia, V.M.F., S. Lu, W.H. He and H.H. Chen, 2006. Non-starch polysaccharide compositions of rice grains with respect to rice variety and degree of milling. Food Chem., 101: 1205-1210. DOI:10.1016/j.foodchem.2006.03.024

16. Bawadi, H.A. and S.A. Sahawneh, 2008. Developing a meal-planning exchange list for traditional dishes in Jordan. J. Am. Diet. Assoc., 108: 840-846. doi:10.1016/j.jada.2008.02.016 
17. Morimoto, J.M., D.M.L. Marchioni and R.M. Fisberg, 2006. Using dietary reference intake-based methods to estimate prevalence of inadequate nutrient intake among female students in Brazil. J. Am. Diet. Assoc., 106: 733-736. DOI:10.1016/j.jada.2006.02.005

18. Department of Statistic, 2005. Food balance sheet 2002-2003. Amman, Jordan.

19. El-Qudah, J.M., B. Dababneh, M.M. Abu Jaber and K.I. Ereifej, 2008. Variation in physio-chemical characteristics, mineral concentrations and cookability of rice marketed in Jordan. Pak. J. Nutrit., 7: 141-145. ISSN: 1680-5194, <http://www.pjbs.org>

20. Food and Nutrition Board, 2004. Dietary Reference Intake: Recommended Intakes for Individuals. Institute of Medicine, National Academies. Washington DC, USA.

21. Association of official analytical chemists, 1984. Official Methods of Analysis. $14^{\text {th }}$ Edn. Washington DC, USA. http://www.aoac.org

22. Ereifej, K.I. and S.H. Gharaibeh, 1993. The levels of cadmium, nickel, manganese, lead, zinc, iron, tin, copper and arsenic in brined canned Jordanian cheese. Z. Lebensum. Unters. Forsch., 197: 123126.

23. Fiske, C.H. and Y. Subbarow, 1925. Colorimetric determination of phosphorus. J. Biol. Chem., 66: 357-400. http:// www.jbc.org <http://www.jbc.org>

24. Steel, R.D.G. and J.H. Torrie, 1982. Principles and procedures of statistics. A Biometrical Approach, $2^{\text {nd }}$ Edn. McGraw Hill Book Co., New York.USA.
25. Freedman, M., J. King and E. Kennedy, 2001. Popular diets: A scientific review. Obesity Res., 9: 1-40. 1-5, DOI:10.1038/oby.2001.113

26. Zhou, Z., R. Keven, H. Stuart and B. Chris, 2002. Composition and functional properties of rice. Int. J.Food Sci. Tech., 37: 849-868.

27. Champagen, E. T. and K. L. Betle, 1999. Rapid visco analyses measurements. Cereal Chem., 76: 764-771.

28. Attenburrow, M., C. Williams, J. Odontiadis, F. Powell, Van de Ouderae, M. Williams and P.J. Cowen, 2003. The effect of a nutritional source of tryptophan on dieting-in 9 duced changes in brain 5 HT Function. Psychol. Med., 33: 1381-1386. DOI: $10.1017 /$ S0033291703008547.

29. Shich, S., R. Wing, M. Klem, M.T. McGuire, J.O. Hill and H. Seagle, 1998. Person successful at long-term weight loss and maintenance continue to consume a low calorie, low fat diet. J. Am. Diet. Assoc., 98: 408-413. DOI: 10.1016/S00028223(98)00093-5.

30. Batres-Marquez, S.P. and H.H. Jensen, 2005. Rice Consumption in the United States: New Evidence from Food Consumption Surveys. Center for Agricultural and Rural Development, Iowa State University, Ames, Iowa 50011-1070. www.card.iastate.edu <http://www.card.iastate.edu $>$ 